\title{
4
}

The Body of Blood / Le Corps du sang 


\title{
Letting or Leaking Blood? Christ's Wounded Masculinity
}

\author{
Leanne Groeneveld
}

Les critiques Leo Steinberg et Caroline Walker Bynum ont voulu démontrer que dans les représentations médiévales du corps $d u$ Christ, l'humanité de celui-ci était représentée par deux symboles qui s'opposent en apparence: son sang (ses plaies) et son pénis. Ce dernier étant vu comme un symbole de masculinité, alors que le sang reste féminin. Cette association simpliste du symbole au genre - et particulièrement $d u$ sang à la féminité - est fausse puisque le genre des corps qui saignent et du sang qui se répand à la fin du Moyen Age repose sur le processus de la perte sanguine. La passion du Christ ressemble davantage à une phlébotomie qu'à des règles de femmes et était d'ailleurs explicitement comparée à cette incision dans les textes.

For twenty years, critics have argued over the gender of Christ in midto late medieval representations of his body. Participants in the debate have tended to agree either with Leo Steinberg, who in The Sexuality of Christ in Renaissance Art and in Modern Oblivion argues for that body's masculinity, or with Caroline Walker Bynum, who in Fragmentation and Redemption: Essays on Gender and the Human Body in Medieval Religion argues for that same body's femininity. Steinberg and Bynum build their respective arguments around different "symbols" (the term used by both) identified as of central importance in determining Christ's figural gender, which in medieval as well as post-modern representations may or may not coincide with the literal or physical.

For Steinberg, that defining symbol is the penis. Noting that "from before 1400 to past the mid-16th century" (3) "renaissance" artists "produced a large body of devotional imagery in which the genitalia of the Christ Child, or of the dead Christ, receive . . . demonstrative emphasis," Steinberg concludes that in the middle ages "one must recognize an ostentatio genitalium comparable to the canonic ostentatio vulnerum, the showing forth of the wounds" (3). Christ's penis, Steinberg argues, "serves as the pledge of God's humanation" (15): 
If the godhead incarnates itself to suffer a human fate, it takes on the condition of being both deathbound and sexed. The mortality it assumes is correlative with sexuality, since it is by procreation that the race, though consigned to death individually, endures collectively to fulfill the redemptive plan. Therefore, to profess that God once embodied himself in a human nature is to confess that the eternal, there and then, became mortal and sexual. (15)

Wounded during the circumcision (a moment never literally, only figuratively depicted, perhaps because disconcerting, even to medieval audiences accustomed to blood), the penis prefigured the Passion (5164). It also, in a number of paintings of the adult Christ as dead or as the Man of Sorrows, prefigured his Resurrection when (disconcerting to modern audiences and critics) it was depicted as erect (81-90).

For Bynum, in contrast, the defining symbol of gender is not a body part but fluid: blood. Without form, it is the feminine to Steinberg's masculine, complicating, even undermining the phallic power of the incarnate god. Blood, Bynum suggests, is an inherently feminine, even female, substance. In representations of Christ's bleeding, open, post-Passion body (ubiquitous in the Middle Ages), it and not the penis serves as the pledge of Christ's humanation (to echo Steinberg). As it does so, it genders all of humanity feminine in relation to a spiritual masculine deity (the much-discussed medieval body/spirit dichotomy); thus Christ is categorized, in a culture desperate above all else to assert the incarnation against heretical claims, as primarily feminine. This is the gender of his substance, but also of his salvic performance. By shedding his blood, Christ gave new life to his creation; by instigating the sacrament of the mass, he fed that new creation with his blood and body. According to medieval medical theory, all body fluids - blood, sweat, milk, semen - were the same substance in various stages of distillation. Thus, Christ's actions, Bynum suggests, are analogous to female reproductive functions: the first corresponds to menstruation, which allows for conception, pregnancy, and new life, the latter, to lactation.

I would like to suggest that, to late medieval Christians, Christ's blood was not an unproblematic and clear sign or symbol of his "femininity." Sometimes, as Bynum asserts, it may have functioned to mark him as somewhat feminine, especially when his lack of agency during and since the Passion was emphasized. At other times, though, his blood marked him as clearly, even impossibly masculine, when his wounds are represented as intentional, weirdly self-inflicted, if effect- 
ed through independent human agents. It matters to his figural gender whether Christ's blood evacuates his body without or with his consent and control, though Bynum conflates both processes or performances, which I will distinguish as menstruation and phlebotomy, and reads them as equally and distinctly feminine or even female.

In its turn, Christ's penis, which Steinberg notices is so central to so many late medieval paintings, as a symbol is probably less, though not completely un-, ambiguous. I would argue, though, that what we today read as its inversion - the bloody, gaping wound - in the Middle Ages could be considered strangely phallic, depending on where, when, and how it bled.

\section{Female/Male Menstruation/Phlebotomy}

The one-sex model central to classical, medieval, and early modern biological and medical science is familiar to those interested generally in issues of gender construction thanks to Thomas Laqueur's groundbreaking study Making Sex. His analysis of medieval theories of sex difference has since been refined and problematized by such critics as Joan Cadden. What has emerged is a theory of sex and gender that conflated, compared, and juxtaposed male and female, masculine and feminine, as it constructed a hierarchy of physical types at once the cause and the effect of the two sexes.

Complexion, it was generally agreed, determined sex. Women were cooler and moister than their male counterparts and so, as a sex, tended to be phlegmatic. The degree to which heat warmed a fetus during its early development in the womb determined its sex - if it formed in the cooler, left chamber of its mother's uterus or was fertilized with weaker (read "cooler") sperm from its father's left testicle, it remained female; if it formed in the hotter, right chamber of its mother's uterus or was fertilized with stronger (read "hotter") sperm from its father's right testicle, it became male (Cadden 130-31).

The fetus "remained" female and "became" male because the latter represented "a higher stage of completion and perfection" (Cadden 171). Citing Aristotle, Commentator B writes in his explication of De Secretis Mulieris [On the Secrets of Women] that "woman is a failed male,

that is, the matter that forms a human being will not result in a girl except when nature is impeded in her actions because of the disposition of the matter and of natural heat, for a particular nature always intends to produce a male and not a female. If a female 
results, this is because of certain factors hindering the disposition of the matter, and thus it has been said that woman is not human, but a monster in nature. (106)

When either parent ingested cold food or drink, when the weather outside was overly warm, or when the wind blew from a direction other than the north, a female child could be produced (Cadden 197). Medieval theorists concluded that nature abhors a female but, when hindered by environmental and parental factors, produces nothing better, and sometimes generates much worse. ${ }^{1}$

Once sexed, the child and adult produced from the fetus acquired features and dispositions determined by the general complexion of its sex as well as its particular dominant humour. A woman could be sanguine for her sex, but since the "general belief was that the coldest man was still warmer than the warmest woman" (Cadden 171), her bodily processes would largely be determined by her sex's relative lack of heat. This lack of heat affected digestion, which it initiated and sustained, and in turn the shape and size of the body, its features, and its various excretions.

Both sexes experienced the same four stages of digestion but because of their different heat levels generated different, though analogous, products, both refined and waste. The first stage of digestion took place in the mouth as the food was chewed and mixed with saliva; the second occurred in the stomach, where nutrition was separated from the superfluity of feces. The third took place in the liver, where chyle transformed into blood; and the fourth took place throughout the body in "individual body members," the most important of which was either the brain, the testicles, or the heart (Women's Secrets 144: Jacquart and Thomasset 52-56).

The third stage of digestion distinguished the male from female body. At this stage, impurities were removed from the chyle to produce blood, a more refined body fluid. The hot male body excreted waste products of this third digestion as sweat or hair; the cooler female body expelled its impurities (or superfluities) as menstruum. The fourth stage of digestion produced semen from that blood not converted into flesh. In the Galenic two-seed model of conception, both male and female bodies produced semen or seed, and so both sexes experienced this final digestive process, though the product in women was cooler, more watery, and generally inferior. In the Aristotelian one-seed model, only the male produced semen; the closest thing to a fourth digestive process in women was the conversion of "pure" men- 
struum into breast milk during and after pregnancy.

Both models emphasized the inferiority of the female body in relation to the male. Cadden writes:

Either men, because of their superior heat, were able to refine their superfluous blood completely into semen, and women, unable to do so, were left with menses; or men, because of their superior heat, produced more, more refined, warmer, less watery semen than women, while women produced inferior semen - and also menses. (173)

Further, menstruum, even if only regarded as a superfluity of blood and not an impurity, was considered harmful and polluting, at very least to the body that produced it, but more commonly as well to other bodies with which it might come into contact. Menstruum represented "excess humidity" that produced "coarse humors . . . which stop up and deaden the brain" and made women "not suited for learning" (Women's Secrets 70). Retained menses (amenorrhea), linked with sterility, could lead to "mania" or madness if not evacuated either from the vagina or (as milk) from the breasts (Cadden 173-74; Jacquart and Thomasset 71; Lanfrank's "Science" 266, 11. 1-20). Once evacuated, menstrual blood prevented crops from germinating, soured grapes and new wine, killed plants and made fruit drop, caused iron objects to rust, and turned dogs rabid (Crawford 59, Jacqart and Thomasset 73, Resnick 245). The breath of a menstruating woman infected open wounds, as did intercourse with her by either patient or doctor (Arderne 88, 11. 9-12; Lanfrank's "Science" 55, 11. 13-17). Her breath made otherwise healthy men hoarse, and her menstrual blood, if it came into contact with a penis during intercourse, caused leprosy or cancer in her foolish partner (Cadden 268; Women's Secrets 88, 130-31). Even the fetus needed to be protected from this poisonous substance. Thomas Aquinas, in his Summa Theologica, suggested that menstruum was the waste product of a distillation process that produced a special, further cleansed and purified blood out of which formed the embryo. "For Aquinas," Jacquart and Thomasset write, "menstrual blood is merely the residue left from the formation of this second blood, and it contains nothing but impurities" (77). Thus, a child conceived during a woman's menstrual period or who for other reasons came into contact with menses before birth often contracted leprosy or small pox (Jacquart and Thomasset 74, 78). 
Despite the physiological superiority of the male sex, individual men sometimes experienced natural, spontaneous purgations that resembled menstruation. Such purgations were unusual and unlikely because men in general were hotter and more able to digest blood in the liver; however, an imbalance of humours or an overabundance of blood could give rise to the need to purge. Cold humours and blood most often passed from the male body via bleeding hemorrhoids, though they could also evacuate from the penis or the nose. Most authorities considered this expulsion of excess perfectly normal. Lanfrank's Science of Cirurgie, a fourteenth-century English translation of a medical treatise by Lanfranco of Milan, insisted that the flux in men should not be treated unless "it blede so myche pat it make pe pacient feble," since it prevents a man from "lepre \& fro mania, \& fro al sijknes pat comep of malancolie" (289, 11. 22-23, 26-27). John Arderne concurred that if anal bleeding "flowe temperatly it dop many helpyngs and preseruep pe body fro many sekenep aduste and corrupte, as is Mania, malencolia, pleuresis, lepre, morfe, ydropisy, mormale, quartane, passions of pe splene, and so of oper like" (57, 11. 27-31). Hemorrhoids had to be treated only if and when the loss of blood led to heaviness in the limbs, loss of appetite, and a "foule colour of body" $(58,1.7)$.

The blood excreted by male melancholics and phlegmatics as well as by men of sanguine character who simply suffered from an excess of blood (because of rich diets and lack of exercise) was like menstrual blood in that its loss constituted a purgation but was unlike menstrual blood in that (in general) it was not considered similarly polluted and polluting. Melancholic blood, when evacuated, was "blak and pikke and stynkyng" (Arderne 60, 11. 19-20) and good for nothing, but no wide-spread taboos appear to have dictated rituals of containment, control, or disposal. Authorities debated whether or not menstruating women should be allowed to enter the church or to take communion, ${ }^{2}$ but men with bleeding hemorrhoids appear to have posed no theoretical or practical problem - unless, of course, they were (or were suspected of being) Jewish, and their bleeding was inflicted by God as a punishment and a curse, supposedly and specifically in response to their cry at Christ's trial "His blood be upon us" (Resnick 259). The divine curse marked and explained the Jews' bloody fluxes as polluted and polluting, as it did women's menstrual periods. Although physiological reasons for the evacuation of blood were put forward and accepted - even for the Jews, who were considered either "naturally" or behaviorally phlegmatic or melancholic ${ }^{3}$ - supernatural inter- 
vention explained why certain bleeding bodies were distinguished from others as worthy of fear and avoidance. Women's menses marked them with the curse they inherited from Eve "to bring forth children in pain" while the Jews experienced their bloody fluxes in part "because of a miracle of God". (Women's Secrets 74). In contrast, Christian men bled only for physiological reasons, to maintain their natural state of health, and so did not need to be controlled or contained.

Nevertheless, their bleeding hemorrhoids sometimes became serious enough to warrant treatment, and when this happened, the preferred therapy was phlebotomy - a controlled bleeding that drained excess fluid or humour before either could worsen existing or create new health problems. A surgical technique considered both curative and preventative and used for a wide range of illnesses, phlebotomy restored balance to the body. Cuts and evacuations were generally made on and from veins on the arms, hands, legs, and ankles, though cuts were made as well on the forehead (to cure headache and "fren$z y$ "); on the temples (to cure "megrim" and eye diseases); behind the ears (for megrim again); on the tongue (for squincy); on the neck, the jugular (for suffocation); and on the lip (for leprosy and infections of the mouth and gums) (Lanfrank's "Science" 301-02, 11. 9-27, 1-7). The scheduling of blood-letting sessions was important, in relation to both the time of day and seasons of the year as well as the age of the patient. The melancholy individual needed bleeding at about the hour of evensong or later, that is, from the ninth hour of the day to the third hour of the night (Arderne 61, 11. 17-21). Phlebotomy was not to be performed when the weather was too hot, since the body was generally empty of liquids and humours at this time, or when it was too cold, since the humours then were too "compatte" and the good were more likely to be evacuated than the evil (Voigts 39-40, 11. 60-71). Phlebotomy was not to be performed during a new moon (Voigts 11. 41, 71-73), nor were surgeons "to cut or cauterise any member of the human body nor to breathe a vein so long as the moon is in the house ruling that member" (Arderne 17, 11. 35-37). The very young (under twelve) were not to be bled, nor were pregnant women, nor were the very old, unless they were unusually strong and healthy.

Physicians were also warned not to let blood from "onge men pat ben white \& pale, \& hauep few heeris in her browis, \& hauep smale veynes and \& priui ... . ne men pat han manie humours \& litil blood." These effeminate men - who include in their number the "Ffrensch" must avoid bleeding because "blood pat is in hem is tresour" (Lan- 
frank 299, 11. 29-32). "It were wel better," Lanfrank's Science opines, that the effeminate man "hadde kept his blood, \& pat pe corrupt humours hadde be voidid awei in oper maner" (300, 11. 3-4). In contrast, physicians were obliged to bleed men whose excess of blood signaled an idle masculinity: excess food and drink was converted in their stomachs to chyle and in their livers to blood while lack of exercise prevented the vast quantities of blood they produced from being put to practical (and less harmful) use. The male body, in this case, operated with expected efficiency, but lifestyle choices - the decision to act like a woman and be idle - created an imbalance that needed to be treated before it led to "diuers sijknes . . \& \& ofte tyme sodeyn deep" (300, 11. 9-10).

The prohibition against bleeding the very young, the very old, and all effeminate youths points at once to phlebotomy's similarity to and radical difference from menstruation as a natural biological process. Because young and old women do not bleed, it stands to reason that young and old men should not be bled. However, young and old men as well as the effeminate youths mentioned by Lanfrank are closer to women in their physiology than are healthy adult males and so, it would seem, more in need of a medical treatment that mimics menstruation. The fact that phlebotomy was not to be performed on the very type of male body that most resembled the female indicates either (or at once) that phlebotomy was considered so similar to menstruation that it would have contributed dangerously, unacceptably so, to the sexual ambiguity of the effeminate man; or (and) that phlebotomy was (supposed to be) so different from menstruation that it could not be used on the sexually ambiguous individual lest the two processes be completely conflated through the medium of the youth's indistinctly sexed body.

Of course, the similarity between the two processes probably led and leads to the necessity of clearly distinguishing them. Gail Kern Paster in The Body Embarrassed: Drama and the Disciplines of Shame in Early Modern England, suggests that "the sign of phlebotomy is menstruation's cultural inversion" (83). She writes:

the most important point about menstrual bleeding is that, unlike the bleedings surgically administered to men and women, menstruation is an involuntary and thus to some degree a punitive process .... It seems to me ... that physiological homology between the involuntary bleeding of the menstruating woman and 
the opened vein of the phlebotomist's patient, whether male or female, serves not to deny but to establish the difference between the two processes as an issue of self-control. $(82,83)$

Phlebotomy could be performed at specific times chosen as optimal for the promotion of health and cure of disease: its performance at certain periods of the day or month or year, then, did not simply mimic natural cycles of menstrual bleeding but improved upon them. Numerous veins and sites on the body could be evacuated, promoting more efficient purgation through the spot reduction of specific amounts of accumulated liquids and humours. The body could be kept closed and contained in unfavourable seasons or during outbreaks of infectious disease. In contrast, female and male menstruation occurred without the individual's consent, flowed to excess or insufficiently, and often occurred at inopportune moments or in dangerous seasons - during the summer months, for example, or during outbreaks of plague.

Paster believes that menstruation in early modern England was regarded "as a particularly charged instance of the female body's predisposition to flow out, to leak" and therefore "served as [one of many] powerful signs of woman's inability to control the workings of her own body" (83). Of course, as discussed above, male bodies sometimes leaked as well and so the open body Paster refers to could (should) be termed feminine rather than female. However, since a woman's optimum state of health would always, in relation to that of the male body, appear pathological, in a state of imbalance, the distinction is perhaps not critical. Regular menstrual evacuations from a female body signified that its biological processes were functioning correctly to deal with inevitable disease; regular or intermittent menstrual evacuations from a male body signified that its biological processes were functioning correctly to deal with an unexpected, unfortunate, even preventable disease. If only phlegmatic and melancholic males would avoid cold, watery foods (raw fruits), they would not need to menstruate (Arderne 59, 1l. 17-19); if only the sanguine man would not eat to excess and would engage in moderate exercise, he would not menstruate either. In contrast, the female had at all times to menstruate, was presented with absolutely no choice. Otherwise, she would become sterile, run mad, or even die. Thus, menstruation was an essential female bodily process that male bodies only sometimes imitated or were forced to perform. When they did either, it was almost always their choice: to be cut or to live a lifestyle that made their bod- 
ies spontaneously bleed. They suffered under no physiological imperative or supernatural curse, as did women and Jews.

\section{Christ's Body: Menstruating or Letting Blood?}

In the Chester Play of Judgement, a late medieval English dramatization of the Second Coming, Christ suggests to the audience that he has, since the moment of his Passion, bled both involuntarily and by choice. He tells the assembled newly-resurrected and crowd of spectators,

\section{I am not as I feele.}

For my bodye ys all torent [torn completely apart] with othes false alwayes fervent [painful, searing]; noe lymme on mee but yt is lent [rent? - torn] ${ }^{4}$ from head right to the heele. (vol. 1, p. 452, 11. 416-20)

Here he repeats and confirms a familiar medieval adage that the swearing of false oaths inflicted fresh wounds on Christ's body and put him to a new painful Passion, against his will and without his consent. Chaucer's Parson famously warns his audience, "For Cristes sake, ne swereth nat so synfully in dismembrynge of Crist by soule, herte, bones, and body," adding, "it semeth that ye thynke that the cursede Jewes ne dismembred nat ynough the preciouse persone of Crist, but ye dismembre hym moore" (Chaucer 307, 1. 590).

Almost immediately following Christ's declaration in the play of his lack of agency, he demonstrates through his actions a simultaneous perfect control over the boundaries of his body and the blood it contains. This time he promises the resurrected and the audience,

Nowe that you shall appertlye [clearly] see

freshe blood bleede, man, for thee -

good to joye and full greate lee [joy, happiness],

the evyll to damnatyon.

Behould nowe, all men! Looke on mee

and see my blood freshe owt flee

that I bleede on roode-tree

for your salvatyon.

Tunc emittet sanguinem de latere eius [Then he will send out blood from his side] (vol.1.,p.453,1l.421-28) If we agree with the distinction between menstruation and phleboto- 
my marked out by Paster, we can read the body in Christ's first speech as undergoing a type of menstruation and the body in his second speech as undergoing a type of intentional evacuation. Significantly, the former can only be imagined since it is not visually represented on stage: Christ tells the audience he does not appear as he "feels," and so his innumerable weeping wounds are not apparent to the spectator's eye. In contrast, Christ's controlled evacuation of blood presents itself to the audience as impressive (and memorable) spectacle. Thus, though an apparently feminine lack of and masculine control are both represented in the person of Christ in the play, the latter is clearly emphasized and privileged.

Elsewhere, the comparison of Christ's suffering to an act of controlled blood-letting is made more explicit - and to a degree that Bynum's suggested connection between the Passion and female menstruation (to my knowledge) nowhere is. For example, according to Joseph Ziegler, Martin of Troppau, a thirteenth-century Dominican, in his sermon 283 on Luke 5.31 ("Those who are well have no need of a physician, but those who are sick") "described Christ's passion as an act of phlebotomy" (182), as did the anonymous English author of the fourteenth-century Fasciculus morum (Ziegler 182, n. 20). Intended as a preacher's handbook, composed around 1300, and apparently very popular - it survives in 28 manuscripts dating up to the end of the fifteenth-century - the latter, the Fasciculus, catalogues all seven deadly sins and presents readers with contrary (and "remedial") virtues (Wenzel 1). In its third section, De Invidia or On Envy, the Fasciculus describes Christ's passion in considerable medical detail:

... Christ shed his blood so that he might wash us from the sickness of guilt. For he taught as a true physician and left the prescription that, however much we are in the grips of a spiritual illness, we are to be bled and thus healed. For Christ was bled as an example for us, yet not in the same way that other men practice, that is, in the arm alone, but rather in his entire body, for as is said in Isaiah: "From the sole of his foot to the top," etc. And his blessed body was certainly well heated when he was fiercely scourged at the column; likewise, it was tightly bound, because it was tightly nailed to the cross by its hands and feet; and likewise, a deep incision was made, because it was pierced in its side with a spear to his very heart. But the consolation which is wont to be shown to

people who are bled, he went totally without. Noblemen and reli- 
gious are bled in pleasant and secret surroundings and receive better food and drink. But Christ was openly put to show before all men on Mount Calvary and was given gall and vinegar to drink, so that we should let our blood spiritually in the same way for his love and our own salvation, that is, we should abstain from sinful deeds to which we are moved by the fleshly nature of our blood; for as Bernard says: "A brave soldier does not feel his wounds when he sees those of his generous leader." $(207,209)$

The conflation of medical and martial metaphors at the end of this passage flags the act of undergoing (and prescribing) phlebotomy as unambiguously masculine. Christ's example - his willingness to suffer public humiliation and to go without the comforts enjoyed by others - recuperates the act of, if not always the patients undergoing, blood-letting from a lurking effeminacy. The noblemen and religious who enjoy "better food and drink" instigate and so deserve the illnesses for which they require treatment (which may include bleeding hemorrhoids, or male menstruation) and are bled in pampered secret, like women. Again, though, because they have chosen their vices, they appear to have more agency than their female counterparts. In contrast to both, Christ exhibits the greatest possible self-control, something that almost resembles a hyper-masculinity, manifested in wounds which, in other circumstances, we might be tempted to misread as feminine.

Yet another comparison of Christ's passion with phlebotomy is made by Ranulphe de la Houblonnière, a secular master who ended his career in 1288 as Bishop of Paris (Ziegler 185). In a sermon delivered on Sunday, 16 April 1273 at the Filles-Dieu, on the subject of the angel's message to the three Marys at Christ's tomb after his death "You seek Jesus of Nazareth: he is risen, he is not here" - Ranulphe explains that the women sought Christ after his death just as a sick patient searches for a physician. Mary Magdalene, their leader, was not foolish ["non fuit stulta"] to lead the women to the tomb and to seek Christ out in this way, since he had earlier demonstrated healing power when he "cured" her of her seven deadly sins (132).

According to Ranulphe, human physicians prescribe their patients five possible treatments: fasting, the taking of medicines, binding, blood-letting, and bathing. Christ, the divine physician, made use of every one of these cures to ensure the spiritual health of humanity. Before the Passion, when tempted in the wilderness, Christ fasted for forty days; during his passion he ingested bitter medicines (the vine- 
gar and gall offered to him), submitted to binding - a treatment for frenzy - during the scourging, and was purged or bled ("minutus fuit") when "they put the nails through his hands and feet, the spear through his side, and the crown of thorns on his head." 5 Finally, once wounded in every part of his body, he was bathed or washed ["balneatus fuit"] in his own healing blood (132).

Remarkably, Christ's patient suffering of these medical procedures served to remedy a disease located not in his own limited, physical body but in the bodies and souls of those individuals who make up his larger corpus, the church. As Joseph Ziegler notes, Christ's ability to cure vicariously, to heal corrupt humanity by treating his own incorrupt flesh, set Him apart as "everything the human physician was not" (186). Ranulphe tells his listeners, "this physician had such compassion for us and our infirmities that he didn't want to do this [impose a painful course of treatment] to us, but instead he did it himself, for us and in our place, taking it upon himself and suffering for our infirmity." 6 Human physicians, it is implied, in contrast have little compassion for their patients. Certainly they lack the desire to suffer in their patients' place as well as the ability to make such suffering in any way curative.

Christ, then, is constructed by Ranulphe as a strange conflation and inversion of human patient and physician. He subjects his perfectly healthy body to an infinitely unnecessary series of medical treatments; the utterly excess benefit that results from these treatments then cures in potentia every imperfect human being ever created. His power of healing is concentrated in his blood, that same blood Bynum believes connects him so closely to women. However, the fact that Christ's blood is taken, not expelled, and that it is purifying, not polluting, connects Christ perhaps more closely to the phlebotomy patient, who could be either male or female and went one step better than menstruating: he or she chose to bleed, as well as from where and for how long.

If the bleeding individual's agency is at all important, we can perhaps even conclude, pace Bynum, that Christ as the Man of Sorrows, wounded fresh by the swearing of oaths (and so wounded apparently against his will and without his consent and control), is more like the menstruating man than like the menstruating woman. Since, as God, he is perfect and incorrupt, there is no essential reason why he needs to bleed. The necessity arises from his choice of lifestyle, his choice to become human, which in turn becomes his disease.

In any case, the ostentatio vulnerum and ostentatio genitalium - the 
showing forth of the wounds and showing forth of the genitals of Christ - noted and remarked upon by Steinberg in medieval art and literature, appear "comparable" in a manner and to a degree previously unanalysed and unconsidered. All of this does not mean that Christ's body was never represented as performing some female/feminine (maternal) functions - gestating the human soul, for example, and/or nourishing that same soul after "birth" with his blood.7 But we need at least to acknowledge that Christ's open, bleeding body, which seems so feminine to modern sensibilities, depending on its construction and context could have seemed ideally masculine to late medieval Christians.

Notes

${ }^{1}$ See, for example, "Chapter 6: Concerning Monsters in Nature" in Pseudo-Albertus' Women's Secrets, 111-120.

2 According to Miri Rubin in Corpus Christi: The Eucharist in Late Medieval Culture, "there seems to have been a tacit acceptance that menstruating women should abstain" (149). This despite Gregory the Great's instruction to Augustine of Canterbury in 597 that a "woman must not be prohibited from entering a church during her usual periods, for this natural overflowing cannot be reckoned a crime: and so it is not fair that she should be deprived from entering the church for that which she suffers unwillingly" (qtd. in Wood, "The Doctor's Dilemma", 714).

${ }^{3}$ It was theorized that Jews had a cold complexion at least in part because they lived in a state of fear and did not exert themselves enough to generate the heat required to burn away superfluities. See Resnick, 261.

${ }^{4}$ Lumiansky and Mills, the editors of the cycle, prefer the variant "rente" found in two manuscripts, Additional 10305 and Harley 2013. They take as their base text Huntington 2 (Chester vol. 2, p. 368, n.419.). ${ }^{5}$ My translation - " quando posuerunt clauos per manus et pedes eius, et in latus lanceam et in capite coronam de spinis" (132).

${ }^{6}$ Again my translation - "Sed iste medicus tantum compassus nobis et infirmitati nostre fuit quod non solum hoc nobis facere uoluit, imo in se, pro nobis et loco nostri, in se habere et pati pro nobis infirmis" (132).

${ }^{7}$ See, for example, The Prickynge of Love, 9-10. 


\section{Works Cited}

Arderne, John. Treatises of Fistula in Ano, Haemorrhoids, and Clysters. Ed. D'Arcy Power. 1910. London: Oxford University Press, 1968. EETS o.s. 139.

Bynum, Caroline Walker. Fragmentation and Redemption: Essays on Gender and the Human Body in Medieval Religion. New York: Zone Books, 1992.

Cadden, Joan. Meanings of Sex Difference in the Middle Ages: Medicine, Science, and Culture. Cambridge: Cambridge University Press, 1993.

Chaucer, Geoffrey. The Riverside Chaucer. Ed. Larry D. Benson. Boston: Houghton Mifflin, 1987.

The Chester Mystery Cycle. Eds. R.M. Luminasky and David Mills. 2 vols. Oxford: Oxford University Press, 1974, 1986. EETS s.s. 3., 9.

Crawford, Patricia. "Attitudes toward Menstruation in SeventeenthCentury England." Past and Present 91 (May 1981): 47-73.

Fasciculus Morum: A Fourteenth-Century Preacher's Handbook. Ed. and trans. S. Wenzel. University Park: Pennsylvania State University Press, 1989.

Jacquart, Danielle, and Claude Thomasset. Sexuality and Medicine in the Middle Ages. Trans. Matthew Adamson. Princeton: Princeton University Press, 1988.

Lanfrank's "Science of Cirurgie". Ed. Robert von Fleischhacker. 1894. Millwood, NY: Kraus Reprint Co, 1973. EETS o.s. 102.

Laqueur, Thomas. Making Sex: Body and Gender from the Greeks to Freud. Cambridge, Mass.: Harvard University Press, 1990.

Paster, Gail Kern. The Body Embarrassed: Drama and the Disciplines of Shame in Early Modern England. Ithaca, NY: Cornell University Press, 1993.

The Prickynge of Love. Vol. 1. Ed. Harold Kane. 2 Vols. Elizabethan \& Renaissance Studies. Salzburg: Insitut für Anglistik und Amerikanistik, 1983.

Ranulphe de la Houblonnière. La Prédication de Ranulphe de la Houblonnière: Sermons aux clercs et aux simples gens à Paris au XIII siècle. Ed. Nicole Bériou. Vol. I. Paris: Etudes Augustiniennes, 1987.

Resnick, Irven M. "Medieval Roots of the Myth of Jewish Male Menses." Harvard Theological Review 93.3 (July 2000): 241-63.

Rubin, Miri. Corpus Christi: The Eucharist in Late Medieval Culture. Cambridge: Cambridge University Press, 1991. 
Steinberg, Leo. The Sexuality of Christ in Renaissance Art and in Modern Oblivion. Second Edition, Revised and Expanded. Chicago: The University of Chicago Press, 1983, 1996.

Voights, Linda E. and Michael R. McVaugh. A Latin Technical Phlebotomy and its Middle English Translation. Philadelphia: The American Philosophical Society, 1984.

Women's Secrets: A Translation of Pseudo-Albertus Magnus' De Secretis Mulierum with Commentaries. Trans. and ed. Helen Rodnite Lemay. Albany: State University of New York Press, 1992.

Wood, Charles T. "The Doctor's Dilemma: Sin, Salvation, and the Menstrual Cycle in Medieval Thought." Speculum 56.4 (October 1981): 710-27.

Ziegler, Joseph. Medicine and Religion c. 1300: The Case of Arnau de Vilanova. Oxford: Clarendon Press, 1998. 